\title{
OPEN
}

\section{Author Correction: Comparison of different smartphone cameras to evaluate conjunctival hyperaemia in normal subjects}

Carles Otero, Nery García-Porta, Juan Tabernero \& Shahina Pardhan

Correction to: Scientific Reports https://doi.org/10.1038/s41598-018-37925-5, published online 04 February 2019

The Article contains an error in the Acknowledgements section.

"Dr. García-Porta is supported by the European Union through the Marie-Sklodowska Curie IF program 2016"

should read:

“This project has received funding from the European Union's Horizon 2020 research and innovation programme under the Marie Skłodowska-Curie grant agreement No 747441"

(c) Open Access This article is licensed under a Creative Commons Attribution 4.0 International License, which permits use, sharing, adaptation, distribution and reproduction in any medium or format, as long as you give appropriate credit to the original author(s) and the source, provide a link to the Creative Commons license, and indicate if changes were made. The images or other third party material in this article are included in the article's Creative Commons license, unless indicated otherwise in a credit line to the material. If material is not included in the article's Creative Commons license and your intended use is not permitted by statutory regulation or exceeds the permitted use, you will need to obtain permission directly from the copyright holder. To view a copy of this license, visit http://creativecommons.org/licenses/by/4.0/.

(c) The Author(s) 2020 